\title{
Postkomunistička tranzicija i vrlina u poslovnoj etici
}

\author{
Stephen Nikola Bartulica*
}

\begin{abstract}
Sažetak
Ovaj članak istražuje stvarnost postkomunističke tranzicije s obzirom na katoličku tradiciju. Nasljeđe totalitarne vladavine vrlo je duboko i ne smije biti zanemareno prilikom razmatranja mogućnosti tih zemalja. Autor navodi kako postoji bitna veza između moralnih vrlina i slobodnog društva s djelotvornom tržišnom ekonomijom. Ako relativistički pristup ostane dominantan u poslovanju i široj kulturi, ne možemo razumski očekivati poboljšanje u budućnosti.

Ključne riječi: vrlina, ljudsko dostojanstvo, komunizam, korupcija, slobodno tržište, katolički socijalni nauk, kultura
\end{abstract}

\section{Uvod}

Većina bi se promatrača složila kako još uvijek nema konačnog odgovora na pitanje utjecaja različitih tranzicijskih politika na neka važna etička pitanja, ali se 28 godina nakon raspada komunizma u Europi ipak mogu donijeti određeni zaključci. Razina korupcije, primjerice, ostala je u nekim zemljama uznemirujuće visoka, što je imalo velikog utjecaja na slabo stanje mnogih ekonomija. Veliki dio stanovništva Srednje i Istočne Europe ostao je nezadovoljan i skeptičan po pitanju prednosti slobodnog tržišta. Možda su očekivanja 1989. jednostavno bila prevelika, a transformacija cjelokupnog političkog i ekonomskog sustava nije bila moguća bez velikih žrtava i društvenih previranja. Ovaj rad će iznijeti stav da se previše pažnje posvetilo izgradnji institucija i donošenju novih zakona, a dublja su moralna pitanja bila zanemarena. Obnova kulturnog krajolika također je bila nedovoljno cijenjen izazov, a tu se pitanje vrline pokazuje od središnje važnosti. Temeljno ljudsko dostojanstvo pod komunizmom nije bilo priznato, jer se režim oslanjao na silu ili nasilje kako bi zadržao red, a to je ostavilo nasljeđe koje se ne može nadići bez prepoznavanja istine o ljudskoj osobi. Komunizam je tijekom svojeg postojanja nanio veliku štetu temeljnim moralnim vrlinama koje su vitalne za slobodno društvo.

* Doc. dr. sc. Stephen Nikola Bartulica, Odjel za povijest, Hrvatsko katoličko sveučilište. Adresa: Ilica 242, 10000 Zagreb, Hrvatska. E-pošta: stjepo.bartulica@unicath.hr 
Katolički socijalni nauk uvijek se protivio bilo kojoj ideologiji koja niječe čovjekovu duhovnu narav. Crkva naučava da je čovjek racionalno i društveno stvorenje i da ga se ne može svesti na puko materijalno biće. Problem s komunizmom nije samo u tome što niječe istinu o čovjeku, nego u praksi uvelike iskrivljuje koncept općeg dobra i drugih temeljnih dobara poput pravde i solidarnosti. Kada država podređuje svakodnevni život unaprijed određenim ciljevima službene ideologije, ljudska osoba pati i njezino dostojanstvo je umanjeno.

$\mathrm{S}$ obzirom na nasljeđe totalitarne vladavine i njegove razorne posljedice za zemlje Srednje i Istočne Europe, pitanje kako obnoviti moralnu kulturu vrlo je važno. Tijekom tranzicijskog procesa 1990-ih dogodila se velika transformacija, koja je uključivala sveobuhvatne pravne, političke, društvene i ekonomske reforme. Uistinu, danas su institucije koje su nam nužne sređene, a gotovo su sve bivše komunističke zemlje članice Europske unije. ${ }^{1}$ Nitko ne može osporiti da pravni okvir za djelotvornu tržišnu ekonomiju sada postoji, ali ostaje činjenica da su poslovi još uvijek izloženi teškim zlouporabama od strane državnih vlasti, a mnogi se poduzetnici žale da tržište nije otvoreno poštenomu natjecanju. S druge strane, opća je javna predodžba da je sustav slobodnog tržišta duboko manjkav te da dovodi do nepravednosti, izrabljivanja, nezasluženih privilegija i moći i nemoralnog stjecanja dobiti.

Nakon objašnjenja teoretske strane pitanja, rad će elaborirati kako se etiku danas shvaća, posebice u tranzicijskim zemljama Srednje i Istočne Europe. Pojavile su se kompanije koje sada obučavaju svoje zaposlenike kako postupati etično i odgovorno. Mnogi promoviraju koncept društveno odgovornog poslovanja kao službenu politiku. Što to zapravo znači i ima li društvo koristi od takve poslovne politike? Jesu li moralne vrline prepoznate kao bitne za odgovorno ponašanje? Neki su iznijeli stav da je društveno odgovorna korporacija temeljna nemogućnost, primjećujući da suprotstavljene dobre i loše karakteristike odnosa između tvrtke i društva u cjelini, zajedno s dinamičnom prirodom njegovih moralnih sankcija, tvrtkama onemogućavaju služenje prepoznatljivim društvenim ciljevima oko kojih se čitavo društvo slaže (Devinney, 2009). Razmotrit ćemo dva ogledna primjera kako bismo procijenili odgovaraju li uključene organizacije adekvatno na potrebu moralne obnove u pogođenim zemljama.

\section{Neuspjeh komunizma}

9. studenog 1989. Berlinski je zid pao, obilježivši kraj komunističkog eksperimenta u Europi. Taj povijesni događaj postao je simbolom kraja Hladnog rata, oslobođenja milijuna ljudi od totalitarne vladavine i liberalizacije nacionalnih ekonomija od ograničenja socijalističkog centralnog planiranja. Francis Fuku-

1 Većina zemalja Srednje i Istočne Europe pridružile su se Europskoj uniji 2004. i 2007. godine. Hrvatska je postala punopravnom članicom 1. srpnja 2013. godine. Makedonija, Bosna i Hercegovina, Srbija, Crna Gora i Albanija u procesu su pridruženja. 
yama slavno je proglasio »kraj povijesti . $^{2}$ Euforiju trenutka dijelili su mnogi, ne samo oni iz bivših komunističkih zemalja, nego i mnogi drugi po cijelom svijetu. Ta euforija, što ne čudi, bila je praćena velikim očekivanjima da će ista razina demokratske slobode i ekonomskog prosperiteta koju uživa napredni Zapad ubrzo postati stvarnost i tih zemalja. Ta očekivanja, prilično neiznenađujuće, nisu bila ispunjena, i do sredine 1990-ih početnu je euforiju u mnogim od tih zemalja zamijenilo razočaranje. ${ }^{3}$

Zastrašujući zadatak transformacije političkog i ekonomskog reda bio je očito nešto što je zahtijevalo vrijeme i što se nije moglo dovršiti bez velikih društvenih prevrata. Među reformama koje je bilo nužno provesti treba spomenuti sljedeće: privatizaciju imovine u državnom vlasništvu velikih razmjera, liberalizaciju trgovine, reformu tržišta rada, pravne reforme koje uključuju porezno, imovinsko i trgovačko pravo, financijske reforme, baš kao i druge. Nije bilo prevladavajućeg konsenzusa o tome kako nastaviti s transformacijom i svaka je zemlja morala razviti svoju vlastitu strategiju i politike. Osim toga, pitanje kako se suočiti sa zloporabom vlasti i kršenjem ljudskih prava pod komunističkom vladavinom postala je glavna politička tema. Što se tiče te teme, iskustva bitno variraju, jer su neke zemlje, poput primjerice Poljske i Češke, uvele lustracijske zakone koji su zahtijevali uklanjanje javnih dužnosnika s njihovih položaja, a druge zemlje, poput Hrvatske i Srbije, nisu donijele takve zakone. ${ }^{4}$

Izvan je dosega ovog rada baviti se pitanjem kako je najbolje suočiti se sa zločinima komunizma. Međutim, ne bismo smjeli podcjenjivati razarajuće posljedice desetljeća totalitarne vladavine. Svakodnevna kršenja temeljnih ljudskih prava i sloboda ostavila su iza sebe traumatizirano stanovništvo. ${ }^{5}$ Ljudi su bili suočeni s egzistencijalnom prijetnjom i morali su pronaći načine preživljavanja pod takvim opresivnim režimom. Kao što je Vaclav Havel rekao, ljudi »nauče živjeti u laži« i nastave sa svojim svakodnevnim izdajama rutinskim pristajanjem, plaćajući svoj dug mašineriji i nadajući se da bi netko negdje mogao znati kako ju isključiti (Havel, 1985, 21). Pisci poput Aleksandra Solženjicina (Solzhenitsyn, 1980a i 1980b) i Leszeka Kołakowskog (2005) smatrali su kako je komunizam zapravo poticao samu suprotnost od kreposnog ponašanja, tj. sustav je nagrađivao ljude koji su bili spremni prihvatiti i promicati njegove laži. Posljedice na moral-

2 Fukuyama piše: »Ono čemu možda svjedočimo nije samo kraj Hladnog rata, ili prolazak određenog razdoblja postratne povijesti, nego kraj povijesti kao takve, tj. krajnja točka ideološke evolucije čovječanstva i univerzalizacija zapadne liberalne demokracije kao konačnog oblika ljudske vladavine « (Fukuyama, 1989, 3).

3 Mora se pažljivo razlikovati stanje između bivših komunističkih zemalja u Srednjoj i Istočnoj Europi. Primjerice, Hrvatska je bila suočena s ratom za neovisnost koji je potrošio njezinu energiju i resurse, zemlje poput Poljske i Češke postigle su bolje ekonomske rezultate od Bugarske i Rumunjske.

4 Lustracijski postupci isključili su sudjelovanje bivših komunista, posebice doušnika komunističke tajne policije, na naslijeđenim političkim položajima, ili čak na položajima u javnim službama. To je isključenje bilo dio šire kampanje dekomunizacije. Od 1996. različiti lustracijski zakoni različitog dosega uvedeni su u Češkoj, Slovačkoj, Mađarskoj, Makedoniji, Albaniji, Bugarskoj, baltičkim zemljama (Litvi, Latviji i Estoniji), Njemačkoj, Poljskoj i Rumunjskoj.

5 Primjerice vidi: Courtois i dr., 1999; Tismaneanu, 2014. 
nu kulturu tih naroda teško je točno izmjeriti, ali može se sa sigurnošću reći da je sam komunistički sustav bio korumpiran. Određujuća je razlika ta da je bilo gotovo nemoguće javno priznati ili osuditi korupciju (disidenti su bili kažnjeni i/ili marginalizirani), nasuprot današnjoj situaciji gdje se o korupciji posve normalno raspravlja i često je se izlaže u medijima. Jedna očita iznimka toj općenitoj primjedbi, naravno, je žestoko protivljenje komunizmu koje je izražavala Katolička crkva u mnogim od tih zemalja. ${ }^{6}$

Postalo je sve jasnije da su u izazivanju urušavanja komunističkog poretka 1989. u velikoj mjeri na djelu bile duhovne sile. Kao što povjesničar s Yalea John Lewis Gaddis objašnjava:

Stvarna je moć tijekom posljednjeg desetljeća Hladnog rata ležala u vođama poput Ivana Pavla II., čije im je ovladavanje neopipljivim vrijednostima — poput hrabrosti, rječitosti, imaginacije, odlučnosti i vjere - omogućavalo da razotkriju nepodudaranje između onoga što su ljudi vjerovali i sustava pod kojima ih je Hladni rat prisiljavao da žive ${ }^{7}$ (Gaddis, 2005, 257).

U svojoj vlastitoj analizi uzroka kolapsa komunizma u Europi papa Ivan Pavao II. naglasio je dublju duhovnu dimenziju kao stvarni izvor promjene. Nakon spominjanja kršenja radničkih prava i neučinkovitosti ekonomskog sustava, on 1991. u enciklici Centesimus Annus navodi sljedeće:

No pravi uzrok novosti jest duhovna praznina što ju je izazvao ateizam, koji je ostavio mlade generacije bez orijentacije te ih nerijetko naveo u neutaživu traženju vlastitog identiteta i smisla života da ponovno otkriju religiozne korijene kulture vlastite nacije i samu Kristovu osobu kao egzistencijalno prikladan odgovor na želju za istinom i dobrom, za životom, koja se nalazi u srcu svakog čovjeka (CA 24).

Moglo bi se reći da su stvari poput potrage za vlastitim identitetom i smislom života stvarnosti koje je nemoguće mjeriti na znanstven način. Povijest pokazuje da ta dublja čežnja za slobodom i dostojanstvom mora biti zadovoljena i da su ljudi spremni trpjeti za „više“" stvari u životu.

Dodatni je važan doprinos enciklike Centesimus Annus to što je prepoznala ono što je odavno trebalo biti jasno - da je moderna država nešto posve novo i ne bi ju se trebalo analitički tretirati kao puki produžetak starog reda koji joj je prethodio (Woods, 2005, 199). Centesimus Annus je, kao što je jedan učenjak primijetio, »prva velika enciklika koja se odnosi prema modernoj državi u skladu s onim što ona jest, barem kako ju je nedavna povijest otkrila: tj. kao potencijalno opasnu koncentraciju prisilne moći koja zahtijeva najstroža pravna i strukturalna ograničenja kako ne bi ugušila ekonomsku sferu s jedne strane, ili kulturno-religijsku s druge. Politička država prikazana u Centesimus Annus nije više klasični ili srednjovjekovni civitas « (Hittinger, 1991, 956). To je važno zato što smo danas dosegnuli točku u kojoj država u bitnom definira svoje vlastite moći. Komunizam

6 Taj je otpor bio najsnažniji u zemljama poput Poljske, Slovačke, Mađarske i Hrvatske, koje imaju znatan udio katoličkog stanovništva. Primjerice, poljski sindikalni pokret Solidarnost bio je snažno povezan s Katoličkom crkvom.

7 Sve citate iz izvora na stranim jezicima na hrvatski je za potrebe ovoga rada preveo autor članka. 
predstavlja jedan krajnji oblik te tendencije, ali nipošto nije jedini. ${ }^{8}$ Problem je što ta tendencija ne izaziva pažnju javnosti, nego je široko prihvaćena kao normalno stanje.

\section{Antropološke pogreške}

Alasdair MacIntyre u knjizi Nakon vrline tvrdi da je marksistički socijalizam u svojoj srži duboko optimističan (MacIntyre, 1981, 262). On uočava duboku kontradikciju u marksističkoj misli kada primjećuje da, s jedne strane, marksisti tvrde da je moralno osiromašenje naprednog kapitalizma veliko, ali s druge strane vjeruju da su preduvjeti bolje budućnosti dosegnuti. Kako se možemo nadati boljoj budućnosti, ako se ljudski resursi za nju trebaju izvesti iz duboko iskvarenog sustava? Taj visoko optimistični pogled na ljudsku narav dijele mnoge revolucionarne ideologije i u suprotnosti je s kršćanskim stajalištem. ${ }^{9}$ Crkvin socijalni nauk uvijek je naglašavao bitnu činjenicu da je naša ljudska narav ranjena grijehom i da je u palom stanju. Crkva proglašava da se »u korijenu osobnih i društvenih razdora koji na razne načine vrijeđaju vrijednost i dostojanstvo ljudske osobe u čovjekovoj nutrini nalazi jedna rana (CSDC 116). Moglo bi se reći da visoka očekivanja brze tranzicije nakon kolapsa komunizma može biti, barem djelomično, pripisana preostalim učincima pretjerano optimističnog shvaćanja ljudske naravi koja je bila implicitno prisutna u službenoj ideologiji tih zemalja.

Postkomunističke zemlje široko se razlikuju u svojim sadašnjim okolnostima i perspektivama, ali sve nose breme povijesnog nasljeđa komunističkih institucija i praksi čija su zajednička obilježja daleko istaknutija od njihovih razlika. Totalitarni komunizam nastojao je atomizirati društvo i uspostaviti potpunu kontrolu nad njime, ne obraćajući pozornost na njegove želje i ne priznajući nijedan zakon iznad volje vladajućih. Evo kako filozof Roger Scruton opisuje savršenu totalitarnu ideologiju: »pseudo znanost koja opravdava i osnažuje ogorčenje, koja potkopava i odbacuje sva suparnička pozivanja na legitimnost i koja obdaruje ne baš uspješne dokazom njihove superiorne intelektualne moći i njihova prava na vladanje« (Scruton, 2006, 153). Ključna riječ u tom odlomku je ogorčenje, nešto što su komunisti vješto koristili kako bi opravdali svoju ideologiju. Danas je problem u tome što ogorčenje ostaje moćna emocija koja je često usmjerena protiv novog uređenja slobodnog tržišta. Ljudi su ogorčeni na uspješne poduzetnike zbog njihova materijalnog uspjeha, a javno mišljenje ostaje sumnjičavo prema ekonomskim slobodama.

Aristotel se također bavio političkom napetošću koja nastaje zbog snažnih nejednakosti između bogatih i siromašnih. Prirodno je da siromašni zavide bo-

8 Moderna država blagostanja također u velikoj mjeri definira svoje vlastite ovlasti, a to je sve više slučaj na razini Europske unije.

9 Primjerice, optimizam o ljudskoj naravi prožima Rousseauovu filozofiju, koja je uvelike utjecala na Francusku revoluciju. Moderni liberalizam je također uvelike pod utjecajem ideje da se ljudska narav može usavršiti pod pravim uvjetima. 
gatima, ili su ogorčeni na njih, kao i to da bogati preziru siromašne i boje ih se. Aristotel situaciju opisuje na sljedeći način:

Tako nastaje grad, ne slobodnih ljudi, nego gospodara i robova, jednih koji preziru, drugih koji su zavidni; a ništa ne može biti smrtonosnije za prijateljstvo i dobro zajedništvo u državama od ovoga: jer dobro zajedništvo izvire iz prijateljstva; kada su ljudi zavidni jedni drugima, ne žele dijeliti zajednički put. Ali grad bi trebao biti sastavljen, koliko god je to više moguće, od jednakih i sličnih; a oni su obično srednja klasa (Aristotel, 4,9).

Strategija komunista bila je iskoristiti prirodne napetosti između bogatih i siromašnih kako bi promovirali svoju političku agendu. Moglo bi se dodati da je to strategija svih pristupa rješavanju društvenih nejednakosti koji se temelje na kolektivizmu ili „,velikoj državi“. Crkva je oduvijek osuđivala takav pristup, kao što je to naglašeno od strane pape Lava XIII. u Rerum Novarum u kojem Sveti Otac navodi: »Da se zlo izliječi, socijalisti raspiruju zavist siromašnih prema imućnima. Oni zahtijevaju da se dokine privatno vlasništvo te mjesto njega uvede zajedničko vlasništvo pod općinskom ili državnom upravom « (RN 4). Crkva je neprestano branila privatno vlasništvo kao naravno pravo i smatrala je socijalistički lijek »izrazito nepravednim« (RN 4). U socijalističkom društvu u kojem se prava na vlasništvo ne poštuju, Papa objašnjava, »nestalo bi privatne inicijative uma i marljivosti pojedinca. Tako bi nužno presušili i izvori bogatstva. Ona zamišljena jednakost ne bi bila drugo nego opća nevolja i bijeda« (RN 15).

Kritika socijalističkih tendencija nije ograničena samo na Katoličku crkvu, jer su slobodnotržišni ekonomisti poput Friedricha von Hayeka i Miltona Friedmana također razotkrili razarajuće posljedice kolektivističkih politika. Osvrćući se na socijalistički pristup, Hayek je ustvrdio sljedeće:

Socijalistička teorija i socijalistička taktika, čak i kada njima ne dominira marksistička dogma, posvuda se temelje na ideji podjele društva na dvije klase sa zajedničkim, ali međusobno suprotstavljenim interesima: kapitalistima i industrijskim radnicima. Socijalizam je računao na brzi nestanak starog srednjeg sloja i potpuno zanemario uspon novog srednjeg sloja (Hayek, 1994, 127).

Taj odlomak ponovno naglašava važnu ulogu srednjeg sloja, po svoj prilici sloja koji je u posjedu vlasništva, u suzbijanju socijalističkih apetita. Jer da bi ijedan kolektivistički sustav mogao prevladati, moć se mora prenijeti s pojedinačnih građana na plansku birokraciju. Hayek je to uočio bolje od ikoga drugoga. Njegovo klasično djelo Put u kmetstvo služi kao upozorenje trenutačnim i budućim generacijama da se kolektivističkoj ideji treba suprotstaviti, kako teorijski, tako i praktično, kako bi se mogla očuvati sloboda. Postoji obilje dokaza da kolektivistički pristup, i u komunističkom i u socijalističkom obliku, ne samo da potkopava slobodu, nego i vrlinu. Razlika je samo u stupnju štete koja se nanosi, kao što se može vidjeti kada se usporedi nasljeđe komunizma s onim moderne države blagostanja. ${ }^{10}$

10 Mora se razlikovati iskustvo totalitarnih komunističkih režima u Srednjoj i Istočnoj Europi i zemalja poput Švedske i Danske, koje su visokorazvijene države blagostanja. U svojoj knjizi Free 
Komunisti su uspjeli koncentrirati političku moć u ruke samoproglašene i samoponavljajuće partijske elite. Privatno vlasništvo koje po svojoj prirodi ograničava državni autoritet bilo je ili ukinuto ili pretvoreno u posjed ovisan o odanom služenju vladajućoj partiji. Prema povjesničaru Richardu Pipesu, tranzicija od planske do tržišne ekonomiji pokazala se iznimno zahtjevnom zato što stanovništvo nije imalo iskustva vođenja privatnih poduzeća i zato što stare komunističke elite nisu gubile vrijeme prilikom prisvajanja državne imovine. Ta je primjedba općenito govoreći točna, jer je iskustvo pokazalo kako su se od 1989. stare elite u svakoj bivšoj komunističkoj zemlji okoristile, ali ne pomaže mnogo u objašnjenju zašto se tranzicija pokazala toliko dugačkom i teškom za sveopće stanovništvo. Zašto je korupcija u tim tranzicijskim zemljama još uvijek raširena? Zašto je toliko teško uspostaviti vladavinu zakona? U sljedećem dijelu istražit ćemo moguće uzroke tog problema

\section{Tranzicija u slobodnotržišnu demokraciju}

Godine 1989. kao jedina prihvatljiva alternativa komunizmu činila se zapadna liberalna demokracija utemeljena na vladavini zakona, slobodnim izborima i temeljnim ljudskim pravima. Iako su stanovnicima Srednje Europe bila priznata građanska prava i dane nove slobode, ta promjena nije odmah bila praćena novom sviješću o osobnoj odgovornosti i dužnostima koje su povezane s pravima. Kako su se liberalne i demokratske institucije postepeno razvijale, politička i moralna kultura je zaostajala, a vodeći političari nisu uspjeli dati dobar primjer. ${ }^{11}$ Nesumnjivo, korupcija nije specifično postkomunistički fenomen, iako nigdje drugdje u Europi ne uzrokuje toliko štete demokratskim i liberalnim institucijama. Unatoč zakonu koji je u skladu s direktivama Europske unije, u postkomunističkim zemljama proces javne nabave, primjerice, ostaje sklon rasprostranjenoj korupciji (Open Society Institute, 2002, 404). Mora se naglasiti kako se korupcija ne koristi isključivo kao »upotreba javne službe za osobnu dobit« (Holmes, 1997, 130). Umjesto toga, koristi se u duhu klasične tradicije, u kojoj se pojam odnosi na suprotnost kreposti te se smatra manjkom građanskih i društvenih vrlina i javnog duha (Pocock, 1975).

U svojoj knjizi Antropologia del Capitalismo Rafael Termes objašnjava kako slobodno tržište potiče važne vrline poput »marljivosti, napornog rada, razboritosti u preuzimanju razumnih rizika, pouzdanosti, odanosti u međuljudski odnosima, [i] odlučnosti u donošenju i izvršavanju zahtjevnih i bolnih odluka« (Termes, 1992, 354). Kada se razmatra o tom popisu, postaje prilično jasno da

to Choose Milton i Rose Friedman u svoju analizu rezultata države blagostanja uključuju gradove poput New Yorka. Prema njima, New York je zajednica koja je najviše orijentirana prema blagostanju u Sjedinjenim Državama, u kojoj je bankrot bio spriječen samo uz pomoć savezne vlade (Friedman i Friedman, 1980).

11 U Hrvatskoj je primjerice bivši premijer Ivo Sanader optužen zbog korupcije i zlouporabe ovlasti u nekoliko slučajeva. 
slobodno tržište ne može pravilno funkcionirati ni procvasti bez svjesnog napora od strane pojedinaca koji su sposobni djelovati odgovorno. U svojoj analizi Pipes naglašava činjenicu da je komunizam lišio ljude iskustva vođenja privatnih kompanija, ali je također sustavno potkopao temeljne moralne vrline koje su ključne za funkcioniranje ekonomije slobodnog tržišta. Kao što teorija vrlina jasno razjašnjava, kako bi se vrlina razvijala, pojedinac mora ponavljati kreposne čine kako bi s vremenom vrline oblikovale njegov karakter. ${ }^{12}$ Ako se osobu ne ohrabruje da prakticira vrlinu ili ju se možda čak kažnjava kada pokušava učiniti pravu stvar, to će neizbježno voditi do deformacije karaktera. Ako se to događa u velikim razmjerima i kroz duže vrijeme, kao pod komunističkim režimima, tada ne bi trebalo čuditi što će tranzicija u slobodno društvo biti izuzetno zahtjevna.

Stvarnost „,postsocijalističkog“ “ čovjeka ili Homo Sovieticus ${ }^{13}$ mora biti uzeta u obzir prilikom istraživanja tranzicijskog iskustva i pitanja shvaćanja poduzetništva u tim zemljama danas. Opisali smo kako je komunizam potkopao njegovanje kreposti u svakodnevnom životu i istovremeno uvjetovao nov način ljudske interakcije i pogleda na stvarnost. Komunizam je imao vlastitu sveobuhvatnu viziju čovjeka i društva koja se odražavala u obrazovanju i formaciji djece, a počinjala je od predškolske dobi i završavana na sveučilištu. Kao što je ranije spomenuto, Crkva je dosljedno isticala kako najvažniji nedostatak komunizma nije ekonomske, nego antropološke prirode. Komunisti su poricali duhovnu narav čovjeka i tako lišili ljude življenja istinski ljudskog života, oblikovavši ih u novi umjetni poredak. Logika komunizma bila je da će zadovoljenje osnovnih potreba dovesti do stabilnog i skladnog reda.

Idući temeljni nedostatak uključuje odnos između čovjeka i države. Ako je čovjek samo materija koju treba oblikovati i preobraziti sukladno volji države, tada je čovjek uistinu u potpunosti podređen državi. Prema tom pogledu, čovjek je rođen kako bi od kolijevke do groba služio državi. Država, dakle, nastavlja umjetno stvarati određene uvjete i odnose koje službena ideologija zahtijeva kako bi postigla utopijske ciljeve jednakosti i sreće za sve. Francuski pravni stručnjak Frederic Bastiat primijetio je kako se za socijaliste »odnos između osoba i zakonodavca čini jednakim odnosu između gline i lončara (Bastiat, 1998, 32). Zapravo, komunisti su podrivali klasično razumijevanje zakona, što je rezultiralo oštrom razlikom između koncepata moralnosti i legalnosti.

Klasična tradicija, najbolje izražena u misli svetog Tome Akvinskog, uvijek je inzistirala na inherentnoj ovisnosti zakona o moralnim načelima. Svrha je zakona prema toj tradiciji voditi ljude prema dobru i stoga on mora biti u skladu s temeljnim načelima pravednosti. Ako bi se to pravilo poštivalo, bilo bi puno manje vjerojatno da će država zloupotrijebiti prava svojih građana. Međutim, kada zakon postane sredstvo za promoviranje određene ideologije, tada nema zaštite od zloporabe moći. Sve je podređeno volji onih na vlasti i nema vladavine zakona, nego je nastalo bezakonje.

12 Vidi: Welchman, 2006; Hartman, 2013.

13 Izraz je osmislio sovjetski pisac i sociolog Aleksandr Zinovyev. 
To je iznimno važno kada se raspravlja o tranzicijskom iskustvu postkomunističkih zemalja. Proces privatizacije u Hrvatskoj, primjerice, bio je opisan od strane jednog crkvenog vođe kao ometen »grijehom struktura «. ${ }^{14}$ Time se htjelo istaknuti činjenicu da je prodaja tvrtki i imovine u državnom vlasništvu možda bila legalna u strogom smislu, ali je istovremeno bila visoko neetična. Ponovljeni pozivi za sveobuhvatnim preispitivanjem procesa odbijeni su uz argument da su odobreni privatizacijski poslovi provedeni prema tada važećim zakonima i nije ih moguće otvoriti za istragu. Stvarnost „ortačkog kapitalizma“ 1990-ih ostavila je dojam da je slobodno tržište samo po sebi nepravedno te da stvara više gubitnika nego pobjednika. Taj dojam uključuje stav da kapitalizam, sam po sebi, vodi do nepravde, izrabljivanja, nezasluženih privilegija i moći, te do nemoralnog stjecanja dobiti. U takvom je općem okruženju od vitalne važnosti iznova potvrditi prednosti ekonomske slobode i objasniti zašto slobodno tržište može olakšati ljudski napredak. Ukratko, ljude se mora uvjeriti u dobrobiti ekonomske slobode i inzistirati da je ona moralno bolja od socijalizma. Tu će zadaću biti mnogo jednostavnije ostvariti ako se poslovi budu vodili na etičniji način u skladu s temeljnim načelima pravde, solidarnosti i poštivanja ljudskog dostojanstva.

\section{Etika i borba protiv korupcije}

Dosad opisana situacija zahtijeva koherentan odgovor od svih društvenih područja, tj. vlasti, civilnog društva, akademske zajednice, poslovne zajednice, osnovnih i srednjih škola itd. Njegovanje vrline, što je ključno za obnovu kulture, zahtijeva svjestan napor od strane obitelji, nastavnika, vjerskih vođa, političkih i poslovnih vođa, baš kao i drugih. Osim toga, promicanje općeg dobra mora se shvatiti kao zadatak za svakoga, ne samo za političke vođe koji su na vlasti. Kao što Crkva podučava, poduzeće se mora odlikovati sposobnošću služenja općemu dobru društva preko proizvodnje dobara i korisnih usluga (CSDC 338). Svaka ljudska djelatnost ima moralnu dimenziju, jer uključuje čovjeka koji je moralni djelatnik.

Usredotočit ćemo se na dva primjera: jedan se odnosi na veliku multinacionalnu kompaniju s naglaskom na aktivnosti u Srednjoj i Istočnoj Europi, a drugi na vladinu antikorupcijsku kampanju u Hrvatskoj. Termin „društveno odgovorno poslovanje“ (DOP) danas se široko koristi i postao je dio službene politike mnogih multinacionalnih i manjih kompanija diljem svijeta. Europska komisija opisuje DOP na sljedeći način: »Odgovornost koju imaju poduzeća za njihov utjecaj na društvo“. (http://ec.europa.eu/growth/industry/corporate-social-responsibility_en)

Katolička crkva vrlo je jasna u naučavanju da uloga poduzeća nije samo stvaranje dobara i vrijednosti za vlasnike, nego i »obavljanje društvene funkcije, stvaranje prilika za susret, suradnju i poboljšanje sposobnosti uključenih ljudi« (CSDC 338). Iz te perspektive, poslovanje se ne može smatrati samo kao »druš-

14 Uzoriti kardinal Josip Bozanić upotrijebio je taj izraz 1998. kada je opisivao političku korupciju u pozadini privatizacijskog procesa u Hrvatskoj. 
tvo kapitalnih dobara«; ono je također »društvo osoba u kojem ljudi sudjeluju na različite načine i sa specifičnim odgovornostima (CA 43). To je personalistički pristup stvarnosti, koji znači da je ljudska osoba uvijek u središtu svake društvene aktivnosti i njezino dostojanstvo ne može se zanemariti ili žrtvovati zbog nekog drugog cilja.

Prvi slučaj društveno odgovornog poslovanja izvještaj je tvrtke PricewaterhouseCoopers (PwC) izrađen 2013. godine pod naslovom Creating value through responsible leadership („Stvaranje vrijednosti kroz odgovorno vodstvo“) za njihove zaposlenike u Srednjoj i Istočnoj Europi (PricewaterhouseCoopers, 2013). Taj dokument naglašava sljedećih pet ciljeva: 1) iskoristiti moć svoje mreže kako biste povećali odgovorna poslovna ponašanja; 2) izgraditi još uključiviju kulturu koja cijeni različitost; 3) povećati pozitivan društveni učinak aktivnosti naše zajednice; 4) upravljati utjecajem na okoliš; i 5) unaprijediti transparentnost i relevantnost našeg izvještavanja o korporativnoj odgovornosti. Izvještaj nadalje ocrtava sljedeće prioritete: strogu usklađenost sa svim propisima i zakonima, snažnu politiku suzbijanja mita, raznolikost i inkluzivnost koja uključuje preko 20 dimenzija s naglaskom na spol.

Odmah je jasno da je ta tvrtka svjesna da su etički standardi važni, ako ne ključni, za njezin uspjeh i dobrobit. Naglasak na transparentnosti i poštivanju svih zakonskih zahtjeva također nije nešto što bi zahtijevalo posebno objašnjenje ili opravdanje. Izraz „povećati pozitivan društveni učinak“ djeluje kao prilično nejasan i podložan različitim tumačenjima. $\mathrm{K}$ tomu, usredotočenost na različitost otvara pitanje zašto se različitost sama po sebi promiče. Ukazuju li nečije etničko podrijetlo, dob, rasa ili spol na njegov moralni karakter? Ako je, kao što smo ustvrdili, etičko ponašanje izravno povezano s moralnim karakterom i vrlinom, tada bi se očekivalo da poduzeća naglašavaju vitalnu važnost toga svojim zaposlenicima. Možemo pretpostaviti da različitost tu ne uključuje zapošljavanje osoblja s različitim pogledima na etičko ponašanje i način na koji se odnose prema klijentima.

Trebamo imati na umu da je PwC multinacionalna korporacija koja djeluje $\mathrm{u}$ cijelom svijetu, ali je taj izvještaj izrađen za zaposlenike u Srednjoj i Istočnoj Europi. Nema naznaka da su autori uzeli u obzir specifične okolnosti koje se odnose na totalitarno nasljeđe tih zemalja. Na prvi pogled, nema ničega kontroverznog vezano za navedene ciljeve i prioritete, jer bismo se svi složili kako je primjerice zaštita okoliša pohvalan cilj, ali to ne mora nužno biti prioritet u zemljama u kojima je okoliš dobro očuvan i koje imaju nisku razinu zagađenja, poput Hrvatske i Slovenije. Nije nam namjera dati sveobuhvatnu procjenu sadržaja tog određenog izvještaja, nego jednostavno primijetiti da ne spominje moralni karakter i vrlinu ni opće dobro kao nešto za čim vrijedi težiti. Druga bitna načela središnja za katolički socijalni nauk, poput solidarnosti i supsidijarnosti, nisu spomenuta u tom izvještaju. Naposljetku, moglo bi se također dodati da bi proglašeni ciljevi i prioriteti bili poželjni bilo u kojoj zemlji, ne samo u onima u Srednjoj i Istočnoj Europi.

Drugi je primjer sveobuhvatna nacionalna antikorupcijska kampanja pokrenuta od strane hrvatske vlade 2006. godine. Ta je kampanja postala Vladin pri- 
oritet u njezinim naporima da završi proces pristupanja punopravnomu članstvu Europske unije, koji je konačno dovršen u srpnju 2013. godine. Osim postojećeg Državnog tužiteljstva, Vlada je osnovala novo tijelo pod nazivom Uredu za suzbijanje korupcije i organiziranog kriminaliteta (USKOK), sa širokim ovlastima u istraživanju i procesuiranju javnih dužnosnika na svim razinama vlasti. USKOK još uvijek postoji, već pet punih godina nakon što se Hrvatska pridružila Europskoj uniji kao punopravna članica.

Ta antikorupcijska kampanja bila je u to vrijeme toplo pozdravljena od strane EU službenika, kao i od strane hrvatske javnosti. Na kraju je bivši hrvatski premijer Ivo Sanader, čija je vlada odlučila pokrenuti inicijativu, bio optužen za uključenost u korupciju te sada čeka novo suđenje u više slučajeva zbog zloporabe ovlasti i korupcije. Otkako je inicijativa pokrenuta, dokazana je povezanost nekoliko visoko rangiranih dužnosnika s kriminalom. Postoji široki konsenzus da su te mjere bile učinkovite u privođenju nekih političara pravdi, iako Hrvatska još uvijek stoji prilično loše na različitim antikorupcijskim ljestvicama. ${ }^{15}$ Unatoč uspješnomu procesuiranju visokih dužnosnika, korupcija još uvijek ostaje glavni problem zemlje.

Jedno je moguće objašnjene te situacije da se slučajevi jednostavno bave učincima koruptivnog ponašanja, a ne uzrocima. Ovdje koristimo izraz korupcija u širem smislu, kako bismo označili prevladavajuće ponašanje u kulturi zemlje. Moglo bi se reći da Vladina antikorupcijska kampanja odražava pristup odozgo prema dolje, tj. država će strožim nametanjem zakona upravljati pravdom i obeshrabriti ljude u koruptivnom ili neetičnom djelovanju u budućnosti. Ali ako se korupciju uistinu želi smanjiti, mora se ići do izvora problema — karaktera pojedine osobe. Taj bi se pristup, utemeljen na usađivanju vrline i oblikovanju moralnog karaktera, moglo okarakterizirati kao pristup odozdo prema gore. Zahtijevao bi da država, primjerice, prilagodi osnovnoškolsko obrazovanje holističkomu pogledu na ljudsku osobu. Naposljetku, bilo bi mnogo razumnije, i vjerojatno jeftinije, spriječiti kriminal i korupciju u budućnosti uvođenjem vrline i zdravog morala, negoli se kasnije baviti posljedicama lošeg ponašanja.

Očiti je problem, naravno, to što u pluralističkom društvu sa svjetonazorskim pogledima na dobro koji se nadmeću, ne postoji konsenzus oko toga kako najbolje podučavati temeljna moralna načela. To je dvojba koja neizbježno nastaje u kulturi u kojoj je filozofski relativizam dominantan. Primjerice, ako bi društvo željelo promovirati poduzetništvo kao nešto dobro i poželjno, iz toga slijedi da bi bio potreban dobro osmišljen napor kako bi se pripremilo djecu za tu stvarnu životnu mogućnost. Međutim, ako postoji neodlučan stav prema poduzetništvu i ekonomskim slobodama općenito, tada će država vrlo vjerojatno biti manje sklona oblikovanju kurikula utemeljenog na vrlini.

15 Vidi primjerice indeks percepcije korupcije međunarodne organizacije Transparency International, prema kojoj je Hrvatska postigla 48 bodova, što je znatno iznad EU prosjeka od 62,5. https:// www.transparency.org/news/feature/corruption_perceptions_index_2017 
Dva izložena primjera ukazuju na poteškoće pri promicanju temeljnih načela poput ljudskog dostojanstva, pravde i općeg dobra u postkomunističkim društvima. Trebali bismo biti realni u vezi s ulogom korporativnog sektora, jer su kompanije samo dio društva i obično nisu pokretačka snaga u pozitivnim društvenim promjenama. Korporacije nastoje biti konzervativne i prilagoditi svoje politike prevladavajućim stavovima i trendovima u široj kulturi. U praksi je malo dokaza da su se spremne angažirati oko dubokih nepravdi - ekonomskih, socijalnih, povijesnih - koje pogađaju mnoge postkomunističke zemlje. Odgovor države također nije bio prikladan, ali to bi se moglo promijeniti ako se predstave koherentni argumenti i stvarna rješenja. Političari se po prirodi po pitanju brojnih odluka oslanjaju na javno mišljenje i često su spremni slijediti, umjesto voditi primjerom. Ako želimo pravednije društvo koje uistinu poštuje ljudsko dostojanstvo, moramo izložiti argumente za to u javnom prostoru.

\section{Zaključak}

Rad je pokazao da je tranzicija u demokraciju i slobodnu ekonomiju bila sporija od očekivanog zbog dugotrajnih posljedica komunističkog nasljeđa u Srednjoj i Istočnoj Europi. Obnova tradicije kršćanskog socijalnog nauksa mogla bi biti važan korak u obnovi kulturnog krajolika. To ne znači da bismo se trebali upuštati u besplodne pokušaje stvaranja „,raja na zemlji“, nego da moramo ustrajati u naviještanju ,istine o čovjeku“, kao što je to na tako uzoran način činio papa Ivan Pavao II. Naposljetku, učinkovitost katolika ovisi o spremnosti na vjernost istini, koja nas dovodi u sukob s prevladavajućim sekularističkim mentalitetom.

Ne treba podcijeniti negativno nasljeđe komunističke vladavine kad je riječ o shvaćanju morala u društvu. Komunistički je poredak kao takav bio duboko korumpiran i nagrađivao je one koji su promovirale njegove laži. Stoga je tranzicija iz totalitarnog društva u slobodno i demokratsko vrlo zahtjevna i dugo će trajati. To vrijedi za sve bivše komunističke zemlje u Europi, ne samo za Hrvatsku.

Rad zaključuje kako postoji vitalna povezanost između moralnih vrlina i slobodnog društva s funkcionalnom tržišnom ekonomijom. Vrline moraju biti jasno definirane i podučavane kako bi utjecale na ponašanje pojedinaca i kompanija. Personalistička vizija čovjeka mora biti dosljedno objašnjena i branjena, kako bi rukovoditelji i menadžeri mogli imati holistički pogled na svoje suradnike i zaposlenike. Ako relativistički pristup ostane dominantan u poslovanju i široj kulturi, ne možemo razumno očekivati poboljšanja u budućnosti.

\section{Literatura:}

Aristotel, Politika, (prijevod Tomislav Ladan), Globus, Zagreb, 1988.

Bastiat, Frédéric (1998). The Law. New York: Foundation for Legal Education.

CA. Centesimus Annus. Ivan Pavao II., Centesimus annus: Stota godina. Zagreb: Kršćanska sadašnjost. 
Courtois, Stéphane; Werth, Nicolas; Panné, Jean-Louis; Paczkowski, Andrzej; Bartošek, Karel; Margolin, Jean-Louis (1999). The Black Book of Communism: Crimes Terror Repression. Preveli s francuskoga na engleski Jonathan Murphy i Mark Kramer. Cambridge, Massachusetts: Harvard University Press.

CSDC. Compendium of the Social Doctrine of the Church. Papinsko vijeće Iustitia et pax, Kompendij socijalnog nauka Crkve. Zagreb: Kršćanska sadašnjost, 2005.

Devinney, Timothy M. (2009). Is the Socially Responsible Corporation a Myth? The Good, the Bad and the Ugly of Corporate Social Responsibility. Academy of Management Perspectives, March 28, 44-56.

European Bank for Reconstruction and Development (2013). Integrity and Anti-corruption Report 2012. London: European Bank for Reconstruction and Development.

Friedman, Milton; Friedman, Rose (1980). Free to Choose: A Personal Statement. New York: Harcourt.

Fukuyama, Francis (1989). The End of History? The National Interest, 16, 3-18.

Gaddis, John Lewis (2005). The Cold War: A New History. New York: Penguin Publishing.

Hartman, Edwin M. (2013). Virtue in Business: Conversations with Aristotle. Cambridge: Cambridge University Press.

Havel, Vaclav (1985). The Power of the Powerless. U: John Keane (ur.), Vaclav Havel et al.: The Power of the Powerless: Citizens against the State in Central-Eastern Europe (str. 23-96). New York: M. E. Sharpe, Inc. Armonk.

Hayek, Friedrich (1994). The Road to Serfdom. Chicago: University Of Chicago Press.

Hittinger, Russell (1991). The Problem of the State in Centesimus Annus. Fordham International Law Journal, 15(4), 952-996.

Holmes, Leslie T. (1997). Corruption in Post-Communist Countries with Particular Reference to Poland. U: Leslie T. Holmes i Wojciech Roszkowski (ur.), Changing Rules: Polish Political and Economic Transformation in Comparative Perspectives (str. 33). Varšava: Institute of Political Studies of the Polish Academy of Sciences.

Kołakowski, Leszek (2005). Main Currents of Marxism: The Origins: The Growth: The Dissolution. New York: W. W. Norton \& Company.

MacIntyre, Alasdair (1981). After Virtue: A Study in Moral Theory. Notre Dame, Indiana: University of Notre Dame Press.

Open Society Institute (2002). Monitoring the EU Accession Process: Corruption and Anticorruption Policy. Budimpešta: Open Society Institute.

Pipes, Richard (2000). Property and Freedom. New York: Vintage Books.

Pocock, John Greville Agard (1975). The Machiavellian Moment: Florentine Political Thought and the Atlantic Republican Tradition. Princeton: Princeton University Press.

PricewaterhouseCoopers (2013). Creating value through responsible leadership: Corporate Responsibility Review 2013: Central \& Eastern Europe. S. 1.

RN. Rerum novarum. Lav XIII., Enciklika Rerum novarum: Enciklika Njegove Svetosti pape Lava XIII. katoličkom svijetu „O stanju radnika“. U: Marijan Valković (ur.), Socijalni dokumenti Crkve: Sto godina katoličkoga socijalnog nauka (str. 1-30). Zagreb: Kršćanska sadašnjost, 1991.

Scruton, Roger (2006). A Political Philosophy: Arguments for Conservatism. London: A\&C Black.

Solzhenitsyn, Aleksandr Isaevich (1980a). East and West: The Nobel Lecture on Literature, $A$ World Split Apart, Letter to the Soviet Leaders, and a BBC Interview. New York: Harper \& Row. 
Solzhenitsyn, Aleksandr Isaevich (1980b). The Mortal Danger: How Misconceptions about Russia Imperil West. New York: Harper \& Row.

Termes, Rafael (1992). Antropologia del Capitalismo. Barcelona: Edicion Agotada.

Tismaneanu, Vladimir (2014). The Devil in History: Communism, Fascism, and Some Lessons of the Twentieth Century. Oakland: University of California Press.

Welchman, Jennifer (ur.) (2006). The Practice of Virtue: Classic and Contemporary Readings in Virtue Ethics. Indianapolis: Hackett.

Woods, Thomas E. (2005). The Church and the Market: A Catholic Defense of the Free Economy. Lanham: Lexington Books.

\section{The Post-Communist Transition and Virtue in Business Ethics}

\section{Stephen Nikola Bartulica*}

\section{Summary}

This article explores the reality of post-communist transition in view of the Catholic tradition. The legacy of totalitarian rule goes very deep and should not be overlooked when examining the prospects of these countries. The author argues that there is a vital connection between moral virtues and a free society with a functioning market economy. If the relativistic approach remains the dominant one in business and the wider culture, we cannot reasonably expect an improvement in the future.

Key words: virtue, human dignity, Communism, corruption, free market, Catholic social teaching, culture

* Stephen Nikola Bartulica, Ph.D., Assistant Professor. History Department, Croatian Catholic University. Address: Ilica 242, 10000 Zagreb, Croatia. E-mail: stjepo.bartulica@unicath.hr 